\title{
Toxicometallomics of Cadmium, Manganese and Arsenic with Special Reference to the Roles of Metal Transporters
}

\author{
Seiichiro Himeno, Daigo Sumi and Hitomi Fujishiro \\ Tokushima Bunri University, Faculty of Pharmaceutical Sciences, Tokushima, Japan
}

\begin{abstract}
The transport systems for metals play crucial roles in both the physiological functions of essential metals and the toxic effects of hazardous metals in mammals and plants. In mammalian cells, $\mathrm{Zn}$ transporters such as ZIP8 and ZIP14 have been found to function as the transporters for $\mathrm{Mn}(\mathrm{II})$ and $\mathrm{Cd}(\mathrm{II})$, contributing to the maintenance of Mn homeostasis and metallothionein-independent transports of Cd, respectively. In rice, the Mn transporter OsNramp5 expressed in the root is used for the uptake of $\mathrm{Cd}$ from the soil. Japan began to cultivate OsNramp5 mutant rice, which was found to accumulate little $\mathrm{Cd}$, to prevent $\mathrm{Cd}$ accumulation. Inorganic trivalent arsenic (As(III)) is absorbed into mammalian cells via aquaglyceroporin, a water and glycerol channel. The ortholog of aquaporin in rice, OsLsil, was found to be an Si transporter expressed in rice root, and is responsible for the absorption of soil As(III) into the root. Since rice is a hyperaccumulator of Si, higher amounts of As(III) are incorporated into rice compared to other plants. Thus, the transporters of essential metals are also utilized to incorporate toxic metals in both mammals and plants, and understanding the mechanisms of metal transports is important for the development of mitigation strategies against food contamination.
\end{abstract}

Key words: Cadmium, Manganese, Arsenic, Silicon, Zinc, Transporter

\section{ROLES OF METAL TRANSPORTERS IN TOXICOMETALLOMICS}

Proteins, nucleic acids, and lipids are essential for the lives of all organisms. From the viewpoint of elemental composition, however, they are composed of a limited number of elements such as $\mathrm{C}, \mathrm{H}, \mathrm{O}, \mathrm{N}, \mathrm{S}$, and $\mathrm{P}$. On the other hand, all prokaryotes and eukaryotes require a variety of metals such as $\mathrm{Ca}, \mathrm{Mg}, \mathrm{Na}, \mathrm{K}, \mathrm{Fe}, \mathrm{Zn}, \mathrm{Cu}, \mathrm{Mn}$, and so on, for survival. These metals constitute important components or cofactors of versatile biomolecules, and influence the functions of proteins, nucleic acids, and lipids. Metallomics is a field of science that aims to elucidate all features of the actions, interactions, structures,

$\overline{\text { Correspondence to: Seiichiro Himeno, Tokushima Bunri University, }}$ Faculty of Pharmaceutical Sciences, Yamashiro, 180, Tokushima 770-8459, Japan

E-mail: himenos@ph.bunri-u.ac.jp

This is an Open-Access article distributed under the terms of the Creative Commons Attribution Non-Commercial License (http:// creativecommons.org/licenses/by-nc/3.0) which permits unrestricted non-commercial use, distribution, and reproduction in any medium, provided the original work is properly cited. transports and roles of metals in biological systems (1).

Although organisms can biosynthesize most proteins, nucleic acids, and lipids, they cannot create metal elements within cells. They must incorporate metals from the extracellular environment via transporters. Therefore, metal transporters are essential to maintaining appropriate amounts of metals within tissues, cells, and organelles for the survival of all organisms. For example, human cells contain 24 types of $\mathrm{Zn}$ transporters, which regulate the influx and efflux of $\mathrm{Zn}$ at the plasma membrane and organelles, and the expression of each $\mathrm{Zn}$ transporter is distinctly regulated in a tissue-, cell-, and organelle-specific manner (2). Dysfunctions of metal transporters may lead to disturbances in metal homeostasis, resulting in the syndromes of metal deficiency or excess.

It has long been known that metals such as $\mathrm{Hg}, \mathrm{As}, \mathrm{Cd}$, and $\mathrm{Pb}$ play no essential role in organisms, and incorporation of excess amounts of these toxic metals causes a variety of diseases in plants, animals, and humans. During the process of evolution, organisms did not develop any specific transporters for cellular incorporation of these toxic metals. Consequently, when toxic metals enter the cells of animals and plants, they utilize the transporters developed 
for other essential metals. This can happen because most metal transporters have a broad spectrum of affinities for multiple metals. To elucidate the mechanisms of cellular accumulation of toxic metals, the identification and characterization of the transporters involved in the transport of both toxic and essential metals are required. From a viewpoint of toxicometallomics, which is a part of metallomics and focuses on the actions, metabolisms, and the effects of chemical forms of toxic metals as well as the interactions of toxic metals with essential metals, elucidation of the transport mechanisms of both toxic and essential metals is crucial for understanding the accumulation modes of toxic metals and for solving the metal contaminations in plants, animals, and humans.

In this review, we briefly describe the roles of metal transporters involved in the transport of $\mathrm{Cd}$ and $\mathrm{Mn}$, as well as those involved in the transport of As, water, and Si in mammals and plants.

\section{TRANSPORTERS FOR CELLULAR INCORPORATION OF Cd AND Mn IN MAMMALS}

It has long been considered that metallothionein (MT), a cysteine-rich metal-binding protein, plays several crucial roles in the transport and accumulation of $\mathrm{Cd}$ in mammalian cells (3). MT can efficiently bind $\mathrm{Cd}$, as well as other metals such as $\mathrm{Zn}, \mathrm{Cu}, \mathrm{Bi}, \mathrm{Hg}$, and $\mathrm{Ag}$, and protect against cytotoxicity of these metals. In the kidney, which is the target organ of chronic toxicity of $\mathrm{Cd}$, the $\mathrm{Cd}$ bound to MT in the blood circulation is readily filtered through the glomerulus, due to its low molecular weight (about 7,000), and then reabsorbed from the lumen to the proximal tubule epithelial cells (PTECs) via megalin-dependent endocytosis $(4,5)$. Since the Cd ions released from the absorbed MT protein within PTECs may continuously induce the synthesis of MT, leading to the binding of Cd ions to the newly synthesized MT protein, the biological half-life of $\mathrm{Cd}$ in the kidney was thought to be very long (6). However, the modes of cellular incorporation of $\mathrm{Cd}$ via pathways other than Cd-MT endocytosis have not been fully elucidated.

To identify non-MT factors, including non-MT transport systems involved in $\mathrm{Cd}$ resistance, we have developed Cd-resistant cell lines from mouse embryonic fibroblast (MEF) cells obtained from MT-I, II knockout mice via stepwise increases in $\mathrm{Cd}$ concentrations in the media (7). The MT-null Cd-resistant cells showed a markedly reduced accumulation of $\mathrm{Cd}$, primarily caused by extremely reduced $\mathrm{Cd}$ uptake rates (7). Since there is no specific transporter for Cd uptake in mammalian cells, it is assumed that expression of the transporter that functions for the uptake of other essential metals, and also has an affinity for $\mathrm{Cd}$, was suppressed in the Cd-resistant MTnull cells. To identify which metal was involved in this suppression of metal uptake, we applied a multi-tracer technique (8). Among 20 metals examined by this technique, $\mathrm{Mn}$ (II) showed a markedly lower uptake rate in $\mathrm{Cd}$ resistant MT-null cells, suggesting that $\mathrm{Cd}(\mathrm{II})$ and $\mathrm{Mn}$ (II) share the same pathway for cellular incorporation (8).

The transport of $\mathrm{Cd}(\mathrm{II})$ and $\mathrm{Mn}$ (II) by the same transporter was also supported by competitive inhibition of the uptakes of $\mathrm{Cd}(\mathrm{II})$ and $\mathrm{Mn}(\mathrm{II})(8,9)$. Subsequent microarray analysis revealed that the expression of ZIP8, a Zn transporter coded by Slc39a8, was suppressed in Cd-resistant MT-null cells compared with parental MT-null cells (10). The role of ZIP8 in Cd transport was confirmed by the reduced uptake of $\mathrm{Cd}(\mathrm{II})$ in the parental MT-null cells transfected with shRNA of ZIP8 (11). The suppressed expression of ZIP8 in Cd-resistant MT-null cells was not due to the mutation of Slc39a8 but to epigenetic hypermethylation of the Slc39a8 gene, because the treatment of Cd-resistant MT-null cells with 5-aza-cytidine, an inhibitor of DNA methyltransferase, led to the recovery of ZIP8 expression, the enhanced uptake of $\mathrm{Cd}$, and consequently, the enhanced cytotoxicity of $\mathrm{Cd}(12)$.

To further examine the role of ZIP8 in Cd resistance, we also established Cd-resistant cell lines from MT-expressing MEF cells and from rat basophilic leukemia RBL-2H3 cells. The latter showed extremely high sensitivity to $\mathrm{Cd}$. Both Cd-resistant cell lines showed suppressed expression of ZIP8 with lowered uptake rates of $\mathrm{Cd}(13,14)$. Interestingly, both Cd-resistant cell lines showed crossresistance to $\mathrm{MnCl}_{2}$ due to the lowered uptake rates of $\mathrm{Mn}(\mathrm{II})$. As the parental RBL-2H3 cells showed higher expression of ZIP8 and higher sensitivity to $\mathrm{MnCl}_{2}$ cytotoxicity than the other rat cell lines examined (15), we also developed Mn-resistant cells from RBL-2H3 cells. As expected, the Mn-resistant RBL-2H3 cells showed a cross-resistance to $\mathrm{Cd}$, accompanied by the suppression of ZIP8 expression and lower uptake rates of both $\mathrm{Mn}$ (II) and $\mathrm{Cd}(\mathrm{II})$ (14). Collectively, the results obtained from Cd-resistant and Mn-resistant cells indicate that ZIP8 plays an important role in the transport of $\mathrm{Cd}(\mathrm{II})$ and $\mathrm{Mn}$ (II) in addition to $\mathrm{Zn}$ (II), and that the lack of ZIP8 expression results in the reduced accumulation and cytotoxicity of $\mathrm{Cd}$ and $\mathrm{Mn}$.

In addition to ZIP8, ZIP14, which has the highest similarity to ZIP8 in its amino acid sequence among ZIP family transporters, was also shown to be involved in the transport of $\mathrm{Cd}(\mathrm{II})$ and $\mathrm{Mn}$ (II) (Fig. 1) in our studies and those of other groups $(16,17)$. The affinities of ZIP8 and two isoforms of ZIP14, ZIP14A and ZIP14B, for Cd(II), $\mathrm{Mn}(\mathrm{II})$, and $\mathrm{Zn}$ (II) have been compared in the mammalian cells and Xenopus oocytes in which these transporters were ectopically expressed (17). The $\mathrm{Km}$ values for the uptake of $\mathrm{Cd}$ (II) $(0.62 \mu \mathrm{M}, 0.10 \mu \mathrm{M}$, and $0.14 \mu \mathrm{M}$ for ZIP8, ZIP14A, and ZIP14B, respectively) were lower than those of $\mathrm{Mn}$ (II) $(2.2 \mu \mathrm{M}, 18 \mu \mathrm{M}$, and $4.4 \mu \mathrm{M}$ for ZIP8, ZIP14A, and ZIP14B, respectively) in mammalian cells, 
(A) Mammalian cell

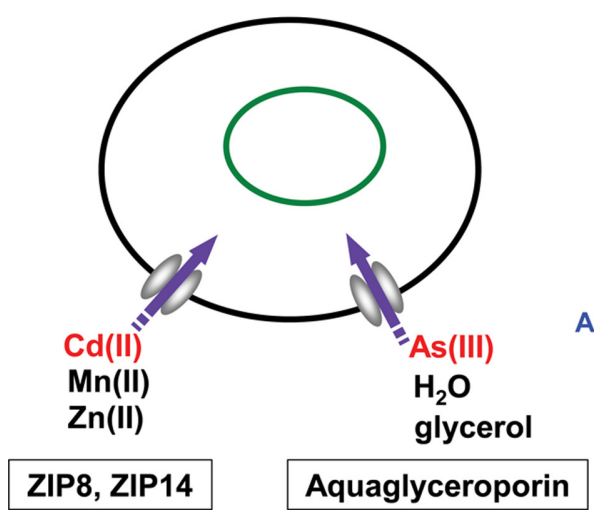

(B) Rice

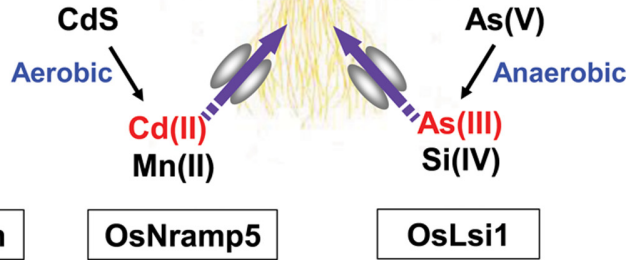

Fig. 1. Schematic illustrations of $\mathrm{Cd}$ and $\mathrm{As}(\mathrm{III})$ uptake via metal transporters in mammalian cells $(A)$ and rice root (B). (A): Among the ZIP family members of Zn transporters, ZIP8 and ZIP14 participate in the transports of Cd(II) and Mn(II) as well as that of Zn(II). The functionalities of ZIP8 and ZIP14 for the transports of $\mathrm{Cd}(\mathrm{II})$ and $\mathrm{Mn}$ (II) have been recognized in a variety of mammalian cells including hepatic (15), renal (21,23), cardiac (15), neuronal (16), intestinal (19), and uterine (8) cells. Cellular uptake of As(III) in mammalian cells is mediated by aquaglyceroporin, a water channel used also for the uptake of glycerol (34-37). (B): In the root of rice, the uptake of $\mathrm{Cd}$ (II) is mediated by the $\mathrm{Mn}$ (II) transporter, OsNramp5 (29), and that of As(III) is mediated by the Si(IV) transporter OsLsi1 (44), which is an ortholog of aquaporin in mammals. Since rice is a hyperaccumulator of Si (42), higher amounts of As(III) is accumulated in rice than other plants. The microenvironment of soil and water surrounding the rice root affect the release of soluble Cd(II) and As(III) from the soil in opposite ways. Under aerobic conditions, the insoluble CdS in soil, which is stable under anaerobic conditions, is oxidized to $\mathrm{CdSO}_{4}$, leading to the release of soluble $\mathrm{Cd}(\mathrm{II})$. In contrast, under anaerobic conditions, the complex of $\mathrm{As}(\mathrm{V})-\mathrm{Fe}(\mathrm{III})$, which is stable under aerobic conditions, is reduced to $\mathrm{As}(\mathrm{III})$ and $\mathrm{Fe}(\mathrm{II})$, leading to the release of soluble $\mathrm{As}(\mathrm{III})$. To achieve the mitigation of $\mathrm{Cd}$ and As contaminations in rice by the management of irrigation water, this trade-off problem should be solved (46-49).

whereas the $\mathrm{Km}$ values for the uptake of $\mathrm{Cd}(\mathrm{II})(0.48 \mu \mathrm{M}$ and $0.46 \mu \mathrm{M}$ for ZIP8 and ZIP14A, respectively) were roughly similar to those of $\mathrm{Zn}(0.26 \mu \mathrm{M}$ and $0.38 \mu \mathrm{M}$ for ZIP8 and ZIP14A, respectively) in Xenopus oocytes (17). These data indicate the high affinity of ZIP8 and ZIP14 for $\mathrm{Cd}(\mathrm{II})$.

A divalent metal transporter 1 (DMT1) also has affinities not only for $\mathrm{Fe}(\mathrm{II})$ but also for $\mathrm{Mn}$ (II) and $\mathrm{Cd}(\mathrm{II})$ (18). Since the expression of DMT1 is high in the intestine $(11,18,19)$, and that of ZIP14 is high in the liver (20), these transporters may play tissue-specific roles in the transport of $\mathrm{Cd}(\mathrm{II})$ and $\mathrm{Mn}$ (II) in different tissues of the body. We found high expression of ZIP8 in the S3 region (straight part) of kidney proximal tubules (21-23). Since it is known that Cd-MT in the glomerular filtrate is mainly reabsorbed in the S1 and S2 regions of proximal tubules $(4,5)$, where megalin-dependent endocytosis largely contributes to the reabsorption of low-molecular-weight proteins, ZIP8 may play a different role in the reabsorption of $\mathrm{Cd}$ not bound to MT in the lumen (24).

To explore the possibility that ZIP8 is involved in the reabsorption of $\mathrm{Cd}(\mathrm{II})$ from the apical side of PTECs, especially at the $\mathrm{S} 3$ region, we carried out an in vitro experiment using immortalized S1, S2, and S3 cells derived from each region of mouse proximal tubules (23). When
Cd(II) was added to the apical side of monolayer S1, S2, and $\mathrm{S} 3$ cells cultured on the membrane of the trans-well, the highest uptake of $\mathrm{Cd}(\mathrm{II})$ was detected in $\mathrm{S} 3$ cells, and the uptake of $\mathrm{Cd}(\mathrm{II})$ from the apical side of $\mathrm{S} 3$ cells was competitively inhibited by $\mathrm{Mn}(\mathrm{II})$ and $\mathrm{Zn}$ (II) (23). This suggests that ZIP8 plays a role in the reabsorption of luminal $\mathrm{Cd}(\mathrm{II})$ in the $\mathrm{S} 3$ region of proximal tubules. However, further in vivo studies are needed to clarify the roles of ZIP8 in renal handling and accumulation of $\mathrm{Cd}$.

Recently, accumulating evidence has shown the role of ZIP8 as an Mn(II) transporter in humans. In Germany and Egypt, congenital glycosylation dysfunctions in infants were found to be related to mutations of human SLC39A8 coding ZIP8 $(25,26)$. Blood Mn levels of these infants were extremely low or undetectable. Since the galactosyl transferase, which is essential for the glycosylation process in the body, is highly dependent on Mn as a cofactor, disturbed metabolism of Mn might have led to the wholebody disorder of glycosylation. Since the excretion rate of Mn from the liver into bile is markedly high, the role of ZIP8 in the epithelial cells of the bile ducts in reabsorbing the Mn excreted to the bile has been considered (27). The ZIP8 expressed in the $\mathrm{S} 3$ region of renal proximal tubules may also be involved in the renal reabsorption of Mn (23), but the physiological roles of ZIP8 in the regulation of 
whole-body Mn homeostasis remain to be elucidated.

Recently, the results of the genome-wide association study (GWAS) showed the links between the SNP of ZIP8 causing amino acid change (p.Ala391Thr) and a variety of conditions such as hypertension, schizophrenia, and other common diseases (28). Future studies will be needed to clarify whether disordered Mn metabolism is involved in these diseases. Thus, greater attention is currently being paid to the roles of ZIP8 not only in Cd transport but also in $\mathrm{Mn}$ transport in humans.

\section{ABSORPTION OF SOIL Cd IN RICE VIA A Mn TRANSPORTER}

For Asian people who eat large amounts of rice as a staple food, the contamination of rice with toxic metals such as $\mathrm{Cd}$ or As is an important issue, and the scientists in the fields of plant physiology and soil sciences are attempting to mitigate the metal contamination of rice. Since plants cannot move like animals, they evolved a variety of transport systems for acquiring necessary metals from the soils. One plant physiology study revealed that OsNramp5 located in the outer membrane of rice root is the transporter responsible for the uptake of $\mathrm{Mn}$ into rice (29). Intriguingly, OsNramp5 also has an affinity for $\mathrm{Cd}$ (Fig. 1), and the knockout of the OsNramp5 gene resulted in almost complete loss of $\mathrm{Cd}$ absorption into the roots and consequently grains of rice (29). Since Mn constitutes the catalytic centers of the water-oxidizing complex of photosystem II in plants, it is inevitable that rice will absorb significant amounts of soil $\mathrm{Cd}$ via the transporter for $\mathrm{Mn}$. Thus, the transport systems for Mn play an important role in $\mathrm{Cd}$ incorporation in rice as well as in mammals.

Recently in Japan, mutant rice, in which the function of OsNramp5 is lost and therefore $\mathrm{Cd}$ is not accumulated, was developed and has begun to be cultivated as a countermeasure against $\mathrm{Cd}$ contamination of rice. This mutant rice was developed using an ion-beam irradiation that can generate a variety of mutations with high specificity in plants (30). Approximately 3,000 rice seeds were irradiated with an ion beam, and three mutants obtained in the next generation seeds were found to produce rice that accumulated no detectable levels of $\mathrm{Cd}$ in their grains even when they were cultivated in Cd-contaminated soil. All three mutant rice varieties were found to have a mutation in the OsNramp5 gene (30). The mutant rice also showed low levels of $\mathrm{Mn}$, but did not show apparent Mn deficiency symptoms such as growth defects, possibly because of the compensatory uptake of Mn by other pathways.

\section{TRANSPORTERS FOR CELLULAR INCORPORATION OF As IN MAMMALS}

Human As poisonings have been extensively reported in
Asian countries, especially in Bangladesh, India, and China, where groundwater is contaminated by inorganic As (iAs) from the earth's crust (31). On the other hand, arsenic trioxide is clinically used for the treatment of acute promyelocytic leukemia (32). Among As compounds, iAs such as arsenite $(\mathrm{As}(\mathrm{III}))$ and arsenate $(\mathrm{As}(\mathrm{V}))$ are highly toxic compared with the methylated forms of As. Therefore, elucidation of the transport systems for iAs is important for understanding the metabolic fates and pharmacological or toxicological effects of As compounds.

The search for the transport systems for As(III) in eukaryotes was triggered by a report showing that the $\mathrm{Sac}$ charomyces cerevisiae strain that lacks the expression of glycerol transporter Fps $1 \mathrm{p}$ exhibited a resistance to As(III) (33). The yeast Fps1p is a protein homologous to the mammalian aquaglyceroporins AQP7 and AQP9. Microinjection of mammalian AQP7 or AQP9 into Xenopus oocytes (34) and that of AQP9 into mouse hepatocytes (35) resulted in enhanced uptake of As(III). AQP3 and AQP10 have also been shown to transport As(III) in mammalian cells (36,37). Aquaglyceroporins (AQP3, 7, 9, and 10) are members of the aquaporin superfamily, which is basically a water channel. However, aquaglyceroporins can also permeate electrically neutral small molecules such as glycerol and urea in addition to water molecules. Since AQP9 is highly expressed in the liver, AQP9 may play an important role in the absorption of As(III) into the liver, the major organ for the metabolism of ingested As compounds (38).

The expression of AQP9 is also detected in human leukemia cell lines such as HL-60 (39). Recently, we found that treatment of HL-60 cells with all-trans retinoic acid, the first-line drug for treatment of acute promyelocytic leukemia, significantly increased the expression of AQP9, leading to an enhanced cellular uptake of As(III) (39). This suggests that co-treatment of leukemic cells with alltrans retinoic acid and arsenic trioxide may enhance the therapeutic efficacy of arsenic trioxide.

$\mathrm{As}(\mathrm{V})$, another form of iAs, is absorbed by phosphate transporters because arsenate has physicochemical properties similar to those of phosphate. In particular, it has been suggested that the intestinal phosphate transporter $\mathrm{NaPiIIb}$ is involved in the absorption of $\mathrm{As}(\mathrm{V})$ into the body (40).

\section{ABSORPTIONS OF As VIA Si TRANSPORTER IN RICE AND ITS TRADE-OFF PROBLEM WITH Cd}

In areas where As poisoning is prevalent, not only groundwater for drinking and cooking but also the rice cultivated with irrigation water derived from As-contaminated groundwater is the source of As ingestion in humans (41). Since As is not an essential element for plants, the absorption of As into rice is mediated by other essential elements, similar to $\mathrm{Cd}$ absorption via the $\mathrm{Mn}$ transporter. 
The rice accumulates higher amounts of As than other plants because of its specific nature as a hyperaccumulator of $\mathrm{Si}$. The content of $\mathrm{Si}$ in rice is as high as $10 \%$ of the total weight, and Si deficiency causes detrimental effects on the rigidity and stress resistance of rice (42). The absorption of $\mathrm{Si}$ in the form of $\mathrm{Si}(\mathrm{OH})_{4}$ from the soil to rice root is mediated by the OsLsil transporter expressed in rice root (43). Intriguingly, OsLsil is an ortholog of mammalian AQP, which is involved in As(III) uptake. It was found that OsLsil has the ability to transport As(III) in addition to Si into rice root (Fig. 1) (44). Thus, rice, as a hyperaccumulator of Si inevitably becomes a hyperaccumulator of As(III). Actually, $60-80 \%$ of As in rice grains is in the form of As(III) (45). Since OsLsi1 plays an essential role in the absorption of $\mathrm{Si}$, its inactivation by mutation or knockout rice could not be achieved.

The solubilities of $\mathrm{As}(\mathrm{III})$ and $\mathrm{As}(\mathrm{V})$ from soil are affected by the oxidizing/reducing conditions of the microenvironment of soil and water around the rice root (46-48). For cultivation of rice, the management of the irrigation water supply is important; water is supplied to (flooding) or drained from (non-flooding) the paddy field depending on the growth periods of rice. The "flooding" causes reducing (anaerobic) conditions in the microenvironment of soils and water surrounding the rice roots due to the blockage of air, while the "non-flooding" causes oxidizing (aerobic) conditions. Under the oxidizing conditions, $\mathrm{As}$ and $\mathrm{Fe}$ form a stable and insoluble complex in the form of $\mathrm{As}(\mathrm{V})-\mathrm{Fe}(\mathrm{III})(\mathrm{OH})_{3}$, whereas under the reducing conditions the reductions of $\mathrm{Fe}(\mathrm{III})$ to $\mathrm{Fe}(\mathrm{II})$ and $\mathrm{As}(\mathrm{V})$ to As(III) occur, leading to the release of soluble As(III) from the soil. Thus, the flooding of rice fields facilitates the release of the soluble form of As(III), and therefore the non-flooding of fields is preferable to minimize the absorption of As(III) into rice, especially at harvest time (45).

Unfortunately, however, the release of soluble $\mathrm{Cd}$ from insoluble $\mathrm{CdS}$ in the soil via the formation of $\mathrm{CdSO}_{4}$ is facilitated under the oxidizing conditions and suppressed under the reducing conditions $(47,49)$. This opposite behavior of $\mathrm{As}$ and $\mathrm{Cd}$ depending on environmental conditions produces a trade-off problem in the mitigation strategy against metal contaminations of rice. Especially in Japan, flooding rice fields at harvest time is recommended as a water management strategy for reducing $\mathrm{Cd}$ accumulation in rice in areas where there is soil contamination of $\mathrm{Cd}$ $(49,50)$; this strategy may, however, increase As accumulation in rice. Since the Codex Alimentarius Commission of $\mathrm{FAO} / \mathrm{WHO}$ has recommended that iAs concentration in polished rice grains be less than $0.2 \mathrm{mg} / \mathrm{kg}$ (51), a solution for this trade-off problem is urgently needed, especially in areas where soil $\mathrm{Cd}$ contamination is detected. The utilization of the low-Cd rice cultivar $(30,52)$ may be one of the warranted solutions for this problem.

\section{CONCLUSIONS}

In this review, recent advances in the study of the transport systems for $\mathrm{Cd}$ and $\mathrm{As}$ in mammals and plants are briefly summarized. In both mammals and plants, transporters originally evolved for the uptake of essential elements such as $\mathrm{Mn}, \mathrm{Zn}$, and $\mathrm{Si}$ are used for the uptake of toxic metals such as $\mathrm{Cd}$ and As. To facilitate the mitigation of metal contamination in plants and animals, a more detailed understanding of the whole profiles of transporting systems for essential and toxic metals is needed.

\section{ACKNOWLEDGMENTS}

This research was partly supported by JSPS KAKENHI Grant Numbers 16H05834 (to SH), 19K12346 (to DS), and 18K06646 (to HF).

\section{CONFLICT OF INTEREST}

The authors have no conflicts of interest to declare.

Received August 29, 2019; Revised September 4, 2019; Accepted September 5, 2019

\section{REFERENCES}

1. Haraguchi, H. (2017) Metallomics: the history over the last decade and a future outlook. Metallomics, 9, 1001-1013.

2. Hara, T., Takeda, T.A., Takagishi, T., Fukue, K., Kambe, T. and Fukada, T. (2017) Physiological roles of zinc transporters: molecular and genetic importance in zinc homeostasis. J. Physiol. Sci., 67, 283-301.

3. Klaassen, C.D., Liu, J., and Diwan, B.A. (2009) Metallothionein protection of cadmium toxicity. Toxicol. Appl. Pharmacol., 238, 215-220.

4. Sabolić, I., Breljak, D., Škarica, M. and Herak-Kramberger, C.M. (2010) Role of metallothionein in cadmium traffic and toxicity in kidneys and other mammalian organs. Biometals, 23, 897-926.

5. Wolff, N.A., Abouhamed, M., Verroust, P.J. and Thévenod, F. (2006) Megalin-dependent internalization of cadmiummetallothionein and cytotoxicity in cultured renal proximal tubule cells. J. Pharmacol. Exp. Ther, 318, 782-791.

6. Elinder, C.G., Lind, B., Kjellstrom, T., Linnman, L. and Friberg, L. (1976) Cadmium in kidney cortex, liver, and pancreas from Swedish autopsies. Estimation of biological half time in kidney cortex, considering calorie intake and smoking habits. Arch. Environ. Health, 31, 292-302.

7. Yanagiya, T., Imura, N., Kondo, Y. and Himeno, S. (1999) Reduced uptake and enhanced release of cadmium in cadmium resistant metallothionein null fibroblasts. Life Sci., $\mathbf{6 5}$, PL177-PL182.

8. Yanagiya, T., Imura, N., Enomoto, S., Kondo, Y. and Himeno, S. (2000) Suppression of a high-affinity transport system for manganese in cadmium-resistant metallothionein-null cells. 
J. Pharmacol. Exp. Ther, 292, 1080-1086.

9. Himeno, S., Yanagiya, T. and Fujishiro, H. (2009) The role of zinc transporters in cadmium and manganese transport in mammalian cells. Biochimie, 91, 1218-1222.

10. Fujishiro, H., Okugaki, S., Nagao, S., Satoh, M. and Himeno, S. (2006) Characterization of gene expression profiles of metallothionein-null cadmium-resistant cells. J. Health Sci., 52, 292-299.

11. Fujishiro, H., Okugaki, S., Kubota, K., Fujiyama, T., Miyataka, H. and Himeno, S. (2009) The role of ZIP8 down-regulation in cadmium-resistant metallothionein-null cells. $J$. Appl. Toxicol., 29, 367-373.

12. Fujishiro, H., Okugaki, S., Yasumitsu, S., Enomoto, S. and Himeno, S. (2009) Involvement of DNA hypermethylation in down-regulation of the zinc transporter ZIP8 in cadmiumresistant metallothionein-null cells. Toxicol. Appl. Pharmacol., 241, 195-201.

13. Fujishiro, H., Kubota, K., Inoue, D., Inoue, A., Yanagiya, T., Enomoto, S. and Himeno, S. (2011) Cross-resistance of cadmium-resistant cells to manganese is associated with reduced accumulation of both cadmium and manganese. Toxicology, 280, $118-125$

14. Fujishiro, H., Ohashi, T., Takuma, M. and Himeno, S. (2013) Suppression of ZIP8 expression is a common feature of cadmium-resistant and manganese-resistant RBL-2H3 cells. Metallomics, 5, 437-444.

15. Fujishiro, H., Doi, M., Enomoto, S. and Himeno, S. (2011) High sensitivity of RBL-2H3 cells to cadmium and manganese: an implication of the role of ZIP8. Metallomics, 3, 710-718.

16. Fujishiro, H., Yoshida, M., Nakano, Y. and Himeno, S. (2014) Interleukin-6 enhances manganese accumulation in SH-SY5Y cells: Implications of the up-regulation of ZIP14 and the down-regulation of ZnT10. Metallomics, 6, 944-949.

17. He, L., Wang, B., Hay, E.B. and Nebert, D.W. (2009) Discovery of ZIP transporters that participate in cadmium damage to testis and kidney. Toxicol. Appl. Pharmacol., 238, 250-257.

18. Gunshin, H., Mackenzie, B., Berger, U.V., Gunshin, Y., Romero, M.F., Boron, W.F., Nussberger, S., Gollan, J.L. and Hediger, M.A. (1997) Cloning and characterization of a mammalian proton-coupled metal-ion transporter. Nature, 388, $482-488$.

19. Fujishiro, H., Hamao, S., Tanaka, R., Kambe, T. and Himeno, S. (2017) Concentration-dependent roles of DMT1 and ZIP14 in cadmium absorption in Caco-2 cells. J. Toxicol. Sci., 42, 559-567.

20. Liuzzi, J.P., Lichten, L.A., Rivera, S., Blanchard, R.K., Aydemir, T.B., Knutson, M.D., Ganz, T. and Cousins, R.J. (2005) Interleukin-6 regulates the zinc transporter Zip14 in liver and contributes to the hypozincemia of the acute-phase response. Proc. Natl. Acad. Sci. U.S.A., 102, 6843-6848.

21. Fujishiro, H., Yano, Y., Takada, Y., Tanihara, M. and Himeno, S. (2012) Roles of ZIP8, ZIP14, and DMT1 in transport of cadmium and manganese in mouse kidney proximal tubule cells. Metallomics, 4, 700-708.

22. Fujishiro, H. and Himeno, S. (2019) Gene expression profiles of immortalized S1, S2, and S3 cells derived from each segment of mouse kidney proximal tubules. Fundam. Toxi- col. Sci., 6, 117-123.

23. Fujishiro, H., Hamao, S., Isawa, M. and Himeno, S. (2019) Segment-specific and direction-dependent transport of cadmium and manganese in immortalized S1, S2, and S3 cells derived from mouse kidney proximal tubules. J. Toxicol. Sci., 44, 611-619.

24. Himeno, S. and Fujishiro, H. (2019) Roles of metal transporters in cellular cadmium transport in mammals in Cadmium Toxicity New Aspects in Human Disease, Rice Contamination, and Cytotoxicity (Himeno, S. and Aoshima, K. Eds.). Springer, Singapore, pp. 163-178.

25. Park, J.H., Hogrebe, M., Fobker, M., Brackmann, R., Fiedler, B., Reunert, J., Rust, S., Tsiakas, K., Santer, R., Grüneberg, M. and Marquardt, T. (2018) SLC39A8 deficiency: Biochemical correction and major clinical improvement by manganese therapy. Genet. Med., 20, 259-268.

26. Park, J.H., Hogrebe, M., Grüneberg, M., Duchesne, I., Von Der Heiden, A.L., Reunert, J., Schlingmann, K.P., Boycott, K.M., Beaulieu, C.L., Mhanni, A.A., Innes, A.M., Hörtnagel, K., Biskup, S., Gleixner, E.M., Kurlemann, G., Fiedler, B., Omran, H., Rutsch, F., Wada, Y., Tsiakas, K., Santer, R., Nebert, D.W., Rust, S. and Marquardt, T. (2015) SLC39A8 deficiency: a disorder of manganese transport and glycosylation. Am. J. Hum. Genet., 97, 894-903.

27. Lin, W., Vann, D.R., Doulias, P.T., Wang, T., Landesberg, G., Li, X., Ricciotti, E., Scalia, R., He, M., Hand, N.J. and Rader, D.J. (2017) Hepatic metal ion transporter ZIP8 regulates manganese homeostasis and manganese-dependent enzyme activity. J. Clin. Invest., 127, 2407-2417.

28. Fujishiro, H. and Himeno, S. (2019) New insights into the roles of ZIP8, a cadmium and manganese transporter, and its relation to human diseases. Biol. Pharm. Bull., 42, 10761082.

29. Sasaki, A., Yamaji, N., Yokosho, K. and Ma, J.F. (2012) Nramp5 is a major transporter responsible for manganese and cadmium uptake in rice. Plant Cell, 24, 2155-2167.

30. Ishikawa, S., Ishimaru, Y., Igura, M., Kuramata, M., Abe, T., Senoura, T., Hase, Y., Arao, T., Nishizawa, N.K. and Nakanishi, H. (2012) Ion-beam irradiation, gene identification, and marker-assisted breeding in the development of low-cadmium rice. Proc. Natl. Acad. Sci. U.S.A., 109, 19166-19171.

31. Yamauchi, H. and Sun, G. (2019) Arsenic Contamination in Asia Biological Effects and Preventive Measures. Springer, Singapore.

32. Zhang, X.W., Yan, X.J., Zhou, Z.R., Yang, F.F., Wu, Z.Y., Sun, H.B., Liang, W.X., Song, A.X., Lallemand-Breitenbach, V., Jeanne, M., Zhang, Q.Y., Yang, H.Y., Huang, Q.H., Zhou, G.B., Tong, J.H., Zhang, Y., Wu, J.H., Hu, H.Y., de Thé, H., Chen, S.J. and Chen, Z. (2010) Arsenic trioxide controls the fate of the PML-RAR $\alpha$ oncoprotein by directly binding PML. Science, 328, 240-243.

33. Wysocki, R., Chéry, C.C., Wawrzycka, D., Van Hulle, M., Cornelis, R., Thevelein, J.M. and Tamás, M.J. (2001) The glycerol channel Fps1p mediates the uptake of arsenite and antimonite in Saccharomyces cerevisiae. Mol. Microbiol., 40, 1391-1401.

34. Liu, Z., Shen, J., Carbrey, J.M., Mukhopadhyay, R., Agre, P. and Rosen, B.P. (2002) Arsenite transport by mammalian aquaglyceroporins AQP7 and AQP9. Proc. Natl. Acad. Sci. 
U.S.A., 99, 6053-6058.

35. Shinkai, Y., Sumi, D., Toyama, T., Kaji, T. and Kumagai, Y. (2009) Role of aquaporin 9 in cellular accumulation of arsenic and its cytotoxicity in primary mouse hepatocytes. Toxicol. Appl. Pharmacol., 237, 232-236.

36. Lee, T.C., Ho, I.C., Lu, W.J. and Huang, J.D. (2006) Enhanced expression of multidrug resistance-associated protein 2 and reduced expression of aquaglyceroporin 3 in an arsenic-resistant human cell line. J. Biol. Chem., 281, 1840118407.

37. Calatayud, M., Barrios, J.A., Vélez, D. and Devesa, V. (2012) In vitro study of transporters involved in intestinal absorption of inorganic arsenic. Chem. Res. Toxicol., 25, 446-453.

38. Tsukaguchi, H., Shayakul, C., Berger, U.V., Mackenzie, B., Devidas, S., Guggino, W.B., Van Hoek, A.N. and Hediger, M.A. (1998) Molecular characterization of a broad selectivity neutral solute channel. J. Biol. Chem., 273, 24737-24743.

39. Sumi, D., Suzukawa, K. and Himeno, S. (2016) Arsenic trioxide augments all-trans retinoic acid-induced differentiation of HL-60 cells. Life Sci., 149, 42-50.

40. Villa-Bellosta, R. and Sorribas, V. (2010) Arsenate transport by sodium/phosphate cotransporter type IIb. Toxicol. Appl. Pharmacol., 247, 36-40.

41. Meharg, A.A. and Rahman, M. (2003) Arsenic contamination of Bangladesh paddy field soils: implications for rice contribution to arsenic consumption. Environ. Sci. Technol., 37, 229-234.

42. Yamamoto, T., Nakamura, A., Iwai, H., Ishii, T., Ma, J.F., Yokoyama, R., Nishitani, K., Satoh, S. and Furukawa, J. (2012) Effect of silicon deficiency on secondary cell wall synthesis in rice leaf. J. Plant Res., 125, 771-779.

43. Jian, F.M., Tamai, K., Yamaji, N., Mitani, N., Konishi, S., Katsuhara, M., Ishiguro, M., Murata, Y. and Yano, M. (2006) A silicon transporter in rice. Nature, 440, 688-691.

44. Jian, F.M., Yamaji, N., Mitani, N., Xu, X.Y., Su, Y.H., McGrath, S.P. and Zhao, F.J. (2008) Transporters of arsenite in rice and their role in arsenic accumulation in rice grain. Proc. Natl. Acad. Sci. U.S.A., 105, 9931-9935.

45. Xu, X.Y., McGrath, S.P., Meharg, A.A. and Zhao, F.J. (2008) Growing rice aerobically markedly decreases arsenic accumulation. Environ. Sci. Technol., 42, 5574-5579.

46. Arao, T., Kawasaki, A., Baba, K., Mori, S. and Matsumoto, S. (2009) Effects of water management on cadmium and arsenic accumulation and dimethylarsinic acid concentrations in Japanese rice. Environ. Sci. Technol., 43, 9361-9367.

47. Moreno-Jiménez, E., Meharg, A.A., Smolders, E., Manzano, R., Becerra, D., Sánchez-Llerena, J., Albarrán, Á. and López-Piñero, A. (2014) Sprinkler irrigation of rice fields reduces grain arsenic but enhances cadmium. Sci. Total Environ., 485-486, 468-473.

48. Hu, P., Huang, J., Ouyang, Y., Wu, L., Song, J., Wang, S., Li, Z., Han, C., Zhou, L., Huang, Y., Luo, Y. and Christie, P. (2013) Water management affects arsenic and cadmium accumulation in different rice cultivars. Environ. Geochem. Health, 35, 767-778.

49. Arao, T. (2019) Mitigation strategies for cadmium and arsenic in rice in Cadmium Toxicity New Aspects in Human Disease, Rice Contamination, and Cytotoxicity (Himeno, S. and Aoshima, K. Eds.). Springer, Singapore, pp. 125-138.

50. Horiguchi, H. (2019) Cadmium exposure and its effects on the health status of rice farmers in Akita prefecture in Cadmium Toxicity New Aspects in Human Disease, Rice Contamination, and Cytotoxicity (Himeno, S. and Aoshima, K. Eds.). Springer, Singapore, pp. 75-83.

51. Codex Alimentarius Commission (2014) Distribution of the report of the eighth session of the Codex Committee on contaminants in foods (REP14/CF). FAO/WHO.

52. Ishikawa, S., Makino, T., Ito, M., Harada, K., Nakada, H., Nishida, I., Nishimura, M., Tokunaga, T., Shirao, K., Yoshizawa, C., Matsuyama, M., Abe, T. and Arao, T. (2016) Lowcadmium rice (Oryza sativa L.) cultivar can simultaneously reduce arsenic and cadmium concentrations in rice grains. Soil Sci. Plant Nutr., 62, 327-339. 